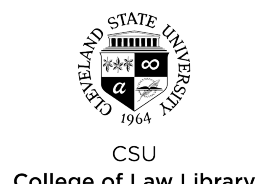

Cleveland State University

College of Law Library

\title{
EngagedScholarship@CSU
}

3-1997

\section{An Implied Cause of Action under the Real Estate Settlement Procedures Act}

Chris Sagers

Cleveland-Marshall College of Law, Cleveland State University, c.sagers@csuohio.edu

Follow this and additional works at: https://engagedscholarship.csuohio.edu/fac_articles

Part of the Antitrust and Trade Regulation Commons, Consumer Protection Law Commons, Property Law and Real Estate Commons, and the Supreme Court of the United States Commons

How does access to this work benefit you? Let us know!

\section{Repository Citation}

Sagers, Chris, "An Implied Cause of Action under the Real Estate Settlement Procedures Act" (1997). Law Faculty Articles and Essays. 1046.

https://engagedscholarship.csuohio.edu/fac_articles/1046

This Article is brought to you for free and open access by the Faculty Scholarship at EngagedScholarship@CSU. It has been accepted for inclusion in Law Faculty Articles and Essays by an authorized administrator of EngagedScholarship@CSU. For more information, please contact research.services@law.csuohio.edu. 


\section{NOTES}

\section{An Implied Cause of Action Under the Real Estate Settlement Procedures Act}

Christopher L. Sagers

\section{INTRODUCTION}

John and Janet lived for most of their early years together in a townhouse in Manhattan. It was a rental, a two-story walk-up on the Upper West Side with barely enough room for the two of them, and it ate up most of their income so that they were barely able to save anything. "Wait a minute," John said one day, "we're paying almost as much for this dump as we'd pay for a mortgage on a nice house!" So the two of them looked over their finances. Not much there. A few thousand and a 401(k) at Janet's work. So John and Janet went to a bank - the Shady Bros. Mortgage \& Loan, up in Westchester. They were going to need a mortgage loan.

The house they picked out, like most mortgaged properties, was subject to various tax and insurance obligations. ${ }^{1}$ When borrowers fail to meet these kinds of obligations, foreclosure is often an inadequate remedy for the lender because the property may be subject to liens superior to the mortgage. ${ }^{2}$ For this reason, Shady Bros., like most real estate lenders, required John and Janet to make periodic deposits into an escrow account, from which charges like the tax and insurance payments could be paid. ${ }^{3}$ The account, like most such accounts, was a savings account, the interest on which the bank retained. ${ }^{4}$

1. Lenders typically require mortgagors to meet two obligations: casualty insurance premiums, intended to protect the lender's interest in the mortgaged property against physical damage, and local real estate taxes. See D. Barlow BurKe, JR., LAw OF Federal MORTgage Documents $\$ 5.1$ (1989); Grant S. Nelson \& Dale A. Whiman, Real Estate FINANCE LAW $\S 4.17$ (2d ed. 1985); Ronald H. Jarashow, Comment, The Improper Use of Tax and Insurance Escrow Payments by Mortgagees, 25 CATH. U. L. Rev. 102, 102 (1975) (describing the mechanics of escrow accounts).

2. See Nelson \& WhItMan, supra note 1, § 4.17. Most importantly, state and local tax obligations will override any interest of the mortgagee. See $i d$.

3. See Nelson \& Whitman, supra note $1, \S 4.17$; George E. Osborne et al., Real Estate FINANCE LAW $\$ 4.18$ (1979) (describing the mechanics of escrow accounts); JAE K. Shim Et AL, Dictionary of Real Estate 104 (1996).

4. See John E. Cribiet \& Corwin W. Johnson, Principles of the Law of Property 170-71 (3d ed. 1989) (describing escrow account procedures and mortgage transactions generally); Jarashow, supra note 1, at 102-04 (detailing the development of escrow accounts and their abuse); Kevin J. Skehan, Note, Enforcement of the Federal Limitation Requirement on Advance Deposits in Escrow Accounts and the Potential Impact on Mortgage Lenders in Connecticut, 12 BRIDGEPORT L. REv. 789, 791-93 (1992) (same). 
Escrow account programs like the one at Shady Bros. first appeared in the 1930 s, at a time when widespread poverty and insolvency led thousands of banks across the nation to adopt similar protections. 5 Over the years, these accounts developed into a lucrative source of interest-bearing capital for mortgage lenders. 6 The practice went virtually unnoticed until the late 1960 s, when borrowers in various states began to challenge the practice alternately as a violation of the Truth in Lending Act, ${ }^{7}$ the antitrust laws, ${ }^{8}$ and common law fiduciary duty, usury, fraud, and other doctrines. 9 When the consumer protection movement of the 1970s finally spurred Congress to enact legislation in this area, it passed the Real Estate Settlement Procedures Act of 1974 ("RESPA"). ${ }^{10}$ RESPA generally limits the ability of lenders to make certain kinds of charges and imposes on them an array of disclosure requirements. ${ }^{11}$ Section 10 of the Act limits the amount that a lender may require a borrower to deposit in an escrow account. ${ }^{12}$

5. See Thomas H. Broadt, Comment, The Attack Upon the Tax and Insurance Escrow Accounts in Mortgages, 47 TEMP. L.Q. 352, 352 (1974); Skehan, supra note 4, at 791-93.

6. See Broadt, supra note 5 , at 352 .

7. 15 U.S.C. $\S \S 1601-1693$ (1994). See Foster v. Maryland State Sav. \& Loan Assn., 369 F. Supp. 843 (D.D.C. 1974); Kinee v. Abraham Lincoln Fed. Sav. \& Loan Assn., 365 F. Supp. 975 (E.D. Pa. 1973); Munn v. American Gen. Inv. Corp., 364 F. Supp. 110 (S.D. Tex. 1973); Umdenstock v. American Mortgage \& Inv. Co., 363 F. Supp. 1375 (W.D. Okla. 1973); Stavrides v. Mellon Natl. Bank \& Trust Co., 353 F. Supp. 1072 (W.D. Pa. 1973).

8. See Kinee, 365 F. Supp. 975; Munn, 364 F. Supp. 110; Umdenstock, 363 F. Supp. 1375; Graybeal v. American Sav. \& Loan Assn., 59 F.R.D. 7 (D.D.C. 1973); Stavrides, 353 F. Supp. 1072.

9. See, e.g., Munn, 364 F. Supp. 110; Umdenstock, 363 F. Supp. 1375; Stavrides, 353 F. Supp. 1072.

10. Pub. L. No. 103-325, 108 Stat. 2221 (codified as amended at 12 U.S.C. $\$ \S 2601-17$ (1994)). Congress's first response to consumer rights advocates was to direct the Department of Housing and Urban Development ("HUD") and the Veterans' Administration to study the problem of excess settlement costs. See Emergency Home Finance Act of 1970, Pub. L. No. 91-351, 84 Stat. 461 (1970); Dale A. Whitman, The Real Estate Settlement Procedures Act: How to Comply - Problems and Prospects, 4 Real Esr. L.J. 223, 223-24 (1976). On the basis of this study, Congress enacted RESPA as a comprehensive regulatory scheme for mortgage lenders. See id. at 224-25.

11. For example, RESPA requires lenders to provide borrowers with a "uniform settlements statement," which sets forth a statement of costs and other information, see 12 U.S.C. $\$ 2603$ (1994), and to disclose to borrowers any transaction involving sale or servicing of mortgage loans. See 12 U.S.C. § 2605(a) (1994).

12. Specifically, section 10 prohibits escrow payments greater than necessary to cover required expenses plus a "cushion" calculated according to a statutory formula. See 12 U.S.C. $\$ 2609$ (a) (1994). This provision may be violated either by requirements that are simply in excess of the permitted amount, or by improper accounting methods. For instance, mortgage lenders commonly use a means of accounting known as "individual item analysis," by which the lender deposits escrow payments into several subaccounts for each type of payment required by law (for example, one for taxes, one for insurance, etc.). Thus, the lender attempts to keep each subaccount at the level permitted by RESPA, making detection of the illegal overcharge quite difficult. See ATtORNEYs GEN. OF CAL., FLA., IOWA, MASS., MINN., N.Y., \& TEX., OVERChaRgING ON MORTGaGes: Violations OF THE EsCROW ACCOUNT LIMITS BY THE MORTGAGE LENDING INDUSTRY 7-12 (1990) (discussing the nature and prevalence of individual item analysis) [hereinafter ATTORNEYS GENERAL REPORT]. 
So, about six years after John and Janet bought the house, they decided they needed a home equity loan to do a little remodeling. But when they visited John's cousin for a little legal advice, she noticed something very peculiar in the couple's first mortgage: it seemed that they were paying too much for the tax and insurance escrow - way too much. They had always grumbled about that tedious bill, but in the face of their tremendous mortgage payment it had hardly seemed worth complaining about.

In many cases, of course, the individual overcharge may be comparatively small. The escrow payment, even when illegally inflated, will still normally represent only a fraction of the overall cost of mortgage financing. ${ }^{13}$ The fact remains, however, that banks that violate section 10 engage in a practice harmful to consumers that Congress has determined should be unlawful. Moreover, whatever the impact on individual consumers, escrow accounts nationwide now represent a huge store of mortgage consumers' funds, ${ }^{14}$ wrongful manipulation of which can result in harms of national scope..$^{15}$

13. In several recent class action settlements, individual payouts have ranged from around $\$ 300$ to over $\$ 1000$. See Jane Bryant Quinn, Truth and Mortgage Escrow Statements, WASH. Post, Feb. 5, 1995, at H2.

14. While it is not known how much of the funds held in escrow accounts nationally are held illegally, it is clear that the numbers are enormous. HUD has estimated that $88 \%$ of mortgage lenders overcharge on escrow payments. See id. In one recent and highly publicized class action settlement, a sole defendant, SunTrust Banks Inc., was alleged to hold more than $\$ 7$ million in illegal funds, see Jack Snyder, SunTrust Denies Charges, ORLANDO SENTINEL, Feb. 10, 1995, at B6, and settled the action for $\$ 2.3$ million, see Jerry Jackson, Mortgage Funds Promised to 40,000, OrLando Sentrinel, Feb. 24, 1996, at D1. In another recent settlement, Burnett Banks of Jacksonville returned $\$ 11.4$ million to over 140,000 mortgagors. See id.

In 1973, the General Accounting Office prepared a study of escrow accounting practices in which it found that total escrow account holdings totaled $\$ 9.4$ billion annually. If escrow payments are collected monthly and disbursed annually, and if homeowners earn the passbook rate of five percent without compounding, the profit to borrowers on the above amount would be roughly $\$ 235$ million per year. See Broadt, supra note 5 , at 352 (discussing the impact of escrow requirements) (citing General Accounting OFFICE, A STUDY OF THE FEAsibility of Escrow AcCounts on Residential Mortgages Becoming INTERest BeARng 7 (1973)); Charles A. Pillsbury, Note, Lender Accountability and the Problem of Noninterest-Bearing Mortgage Escrow Accounts, 54 B.U. L. REv. 516, 517 n.7 (1974).

15. Instability in the housing industry can cause severe macroeconomic harms in the United States. Declines in new housing construction result in widespread shutdowns in the building industry and curtail activities in related industries. See KENNETH T. ROSEN, AFFORDABLE HOUSING 61,77-78 (1984) (discussing macroeconomic effects of weaknesses in the housing industry). Housing finance costs, in tum, play a direct role in such declines-demand for new housing has been shown to be quite price elastic. See id. at 75-76 (summarizing econometric study of demand for new housing), primarily because housing starts are overwhelmingly dependent on the costs and availability of mortgage financing. See Leo Grebler \& Sherman J. Maisel, Determinants of Residential Construction, in IMPACTS OF MONETARY PoLrcy 475, 491 (Commission on Money and Credit ed., 1963) (finding that a range of economic research showed "that short-run fluctuations in residential building have resulted mainly from changes in financial conditions labeled as ease of borrowing, availability of mortgage funds, or supply of mortgage credit"); see also id. at 532-33, 536-37 (explaining the importance of including a "credit variable" in econometric models of the housing market). Thus, if demand for new housing is highly price elastic, then small increases in the cost of mortgage credit will cause comparatively large decreases in housing starts. Therefore, even 
Unfortunately for John and Janet, and millions of home loan borrowers like them, section 10 is silent with respect to the remedy for a violation of the escrow payment limitation. ${ }^{16}$ Therefore, borrower plaintiffs must argue that courts should recognize an implied cause of action under that section. ${ }^{17}$ Unfortunately for consumers, federal courts of appeals disagree as to whether such a private action exists. ${ }^{18}$

This Note contends that consumers should have a private damages action under section 10. Part I discusses the method federal courts currently employ to determine whether a private cause of action should be recognized under a given federal statute. Part II applies this standard to section 10 , and it argues that, although the federal courts currently exhibit a fairly restrictive attitude toward implication of remedies, an action should be.implied under section

the comparatively small overcharges associated with home mortgage escrows will discourage those consumers who are otherwise at the margin - presumably, low- and middle-income families - from purchasing homes. The Congress that enacted RESPA was fully apprised of the potential macroeconomic impacts of excessive settlement costs. See S. REP. No. 93-866, at 13 (1974) (additional views of Sen. Proxmire) ("In many cases, high settlement charges have depressed the housing market by making it impossible for moderate income families to afford to purchase a home.").

16. Typically, borrowers seek a remedy in the form of a civil suit for money damages in the amount of the overcharge. See, e.g., DeBoer v. Mellon Mortgage Co., 64 F.3d 1171 (8th Cir. 1995). Section 10 actions are usually brought along with several other causes of action based on the wide range of legal constraints placed on lenders. See, e.g., Louisiana v. Litton Mortgage Co., 50 F.3d 1298 (5th Cir. 1995) (section 10 claim brought along with actions under RICO and the Louisiana Unfair Trade Practices and Consumer Protection Act); Allison v. Liberty Sav., 695 F.2d 1086 (7th Cir. 1982) (state consumer protection statute); Katz v. Bank of Cal., 640 F.2d 1024 (9th Cir. 1981) (Truth in Lending, and RESPA claims other than section 10); Vega v. First Fed. Sav. \& Loan Assn., 622 F.2d 918 (6th Cir. 1980) (same); Adamson v. Alliance Mortgage Co., 677 F. Supp. 871 (E.D. Va. 1987) (RICO, Truth in Lending, and breach of contract claims). Section 10 actions have also frequently been brought as class actions by one borrower plaintiff as a class representative, see, e.g., Herrmann v. Meridian Mortgage Corp., 901 F. Supp. 915 (E.D. Pa. 1995); Lake v. First Nationwide Bank, 900 F. Supp. 726 (E.D. Pa. 1995); Michels v. Resolution Trust Corp., No. 4-93-1167, 1994 WL 242162 (D. Minn. Apr. 13, 1994), or by a governmental entity as parens patriae, see, e.g., Litton, 50 F.3d 1298.

17. See, e.g., Litton, 50 F.3d at 1300; Allison, 695 F.2d at 1087; Vega, 622 F.2d at 925 n.8.

18. The Sixth Circuit recognizes an implied cause of action. See Vega, 622 F.2d at 925 n.8. The Fifth Circuit, see Litton, 50 F.3d at 1301, and the Seventh Circuit, see Allison, 695 F.2d at 1091, explicitly reject the Sixth Circuit's reasoning, and the Eighth Circuit, although it has not yet ruled on the issue, has expressed doubts conceming whether a cause of action exists, see DeBoer, 64 F.3d at 1177.

One federal district court in the Third Circuit addressed this issue tangentially. See Lake v. First Nationwide Bank, 156 F.R.D. 615 (E.D. Pa. 1994). Lake highlights the irony of the refusal to recognize a section 10 cause of action. The implication issue arose in Lake in the context of a class action settlement motion. The court, relying primarily on Allison, expressed serious doubt that the plaintiffs could succeed on their section 10 money damages action. See 156 F.R.D. at 627 . The court accepted the settlement, however, explaining that the very weakness of the plaintiffs' claim gave the settlement greater force. This was so, the court continued, because the settlement would deter the defendant bank from future section 10 violations. See 156 F.R.D. at $627-28$. As this Note argues in great detail, the courts could bring about this same deterrence in all cases merely by giving effect to Congress's manifest purpose and recognizing an implied action under section 10. 
10 because RESPA was enacted at a time when Congress relied on a more permissive judicial implication doctrine. Finally, Part III contends that a private action for money damages is superior to other potential forms of enforcement.

\section{IMPled Rights of Action Under Federal Statutes}

Since the mid-1970s, the Supreme Court has issued several opinions curtailing the power of the federal courts to fashion innovative remedies, even when to do so would further the interests Congress sought to protect. Thus, if RESPA were enacted in its present form today, a claim for an implied cause of action would probably fail. ${ }^{19}$ However, the Court has recognized that the doctrine of implied actions was quite permissive for many years prior to the conservative turn of the 1970s - some time after RESPA's passage. At the time Congress enacted RESPA, it likely was aware of the Court's prior precedents. As one commentator noted:

If application of the new stricter test to statutes enacted when Congress most likely anticipated that the Court would apply the thenexisting, broader approach produces different results on the question of implied liability, then one of two events must occur to reestablish the status quo ante: either, sua sponte, Congress must divert its attention from its own pressing legislative priorities to reinstitute the prior approach ... or the people disadvantaged by this judicially initiated change in the status quo must bear the costs . . . 20

The Supreme Court has recognized this problem and, as will be discussed more fully below, ${ }^{21}$ has held that, as a general matter, the law that existed when a statute was enacted is relevant to its interpretation. ${ }^{22}$ This Part therefore summarizes the law of implication as it existed when RESPA was passed and attempts to synthesize the various approaches of present-day federal courts interpreting statutes enacted at that time.

19. When a modern statute is silent with respect to remedy, courts will recognize an implied action only in rare circumstances. See infra notes 33-35 and accompanying text. Neither the explicit language of section 10 nor its legislative history mention enforcement in any way. Thus, it is unlikely that, if section 10 were enacted today, courts would recognize a private action.

20. Robert H.A. Ashford, Implied Causes of Action Under Federal Laws: Calling the Court Back to Borak, 79 Nw. U. L. REv. 227, 233 (1984).

21. See infra notes $36-52$ and accompanying text.

22. See, e.g., Central Bank of Denver v. First Interstate Bank of Denver, 511 U.S. 164, 173 (1994) (noting that when construing older statutes, courts may consider the larger legal context in which the statutes were enacted if the circumstances so require); Merrill Lynch, Pierce, Fenner \& Smith, Inc. v. Curran, 456 U.S. 353, 378-82 (1982) (holding that statutory interpretation must proceed with a consideration of the "contemporary legal context" in which a statute was enacted). 
For most of this century, the leading case on implied actions was Texas \& Pacific Railway $v$. Rigsby. ${ }^{23}$ In that case, the Supreme Court reasoned that "[a] disregard of the command of the statute is a wrongful act, and where it results in damage to one of the class for whose especial benefit the statute was enacted, the right to recover the damages from the party in default is implied."24 Rigsby drew heavily upon British doctrines of implied tort liability based on criminal statutes. ${ }^{25}$ Like the British courts, American courts adhered for the most part to the maxim ubi jus ibi remedium - where there is a right, there is a remedy. ${ }^{26}$ Therefore, until the 1970s, courts focused almost exclusively on whether a private cause of action would serve the purposes of a statute. ${ }^{27}$

23. 241 U.S. 33 (1916). See Ashford, supra note 20, at 246-47; Thomas L. Hazen, Implied Private Remedies Under Federal Statutes: Neither a Death Knell Nor a Moratorium - Civil Rights, Securities Regulation, and Beyond, 33 VaND. L. REv. 1333, 1335 (1980). The doctrine is much older than Rigsby, however, and has been applied throughout U.S. history. See, e.g., Marbury v. Madison, 5 U.S. (1 Cranch) 137, 163 (1803) (" $[\mathrm{I}] \mathrm{t}$ is a general and indisputable rule, that where there is a legal right, there is also a legal remedy by suit, or action at law, whenever that right is invaded."). See generally Merrill Lynch, 456 U.S. at 375 n.54 (citing cases).

24. Rigsby, 241 U.S. at 39.

25. See 241 U.S. at 40 (citing Couch v. Steel, 118 Eng. Rep. 1193, 1196 (Q.B. 1854)). See generally 9 Louis Loss \& Joel Seligman, Securities Regulation 4313 n.284 (1989) (examining British doctrine and early American reliance on it); Hazen, supra note 23, at 1335-36 ("Implication of a private remedy based upon penal legislation is an off-shoot of the doctrine of negligence per se.").

26. See, e.g., Rigsby, 241 U.S. at $39-40$ (stating $u b i$ jus as rule of decision); $c f$. Fitzgerald v. Pan Am. World Airways, 229 F.2d 499, 501 (2d Cir. 1956) ("Consequently, by implication ... [the statute] creates an actionable civil right for the vindication of which a civil action may be maintained ...."); Fischman v. Raytheon Mfg., 188 F.2d 783, 787 (2d Cir. 1951) ("Since [the statute] does make 'unlawful' the conduct it describes, it creates such a remedy."); Reitmeister v. Reitmeister, 162 F.2d 691, 694 (2d Cir. 1947) ("[I]n the absence of contrary implications, ... a criminal statute, enacted for the protection of a specified class, [creates] a civil right in members of the class."); Goldstein v. Groesbeck, 142 F.2d 422, 427 (2d Cir. 1944) (arguing that a private action is necessary or the policy of the legislation would go unenforced); Baird v. Franklin, 141 F.2d 238, 244-45 (2d Cir. 1944) ("[I]f the . . p public is to be completely and effectively protected, [the statute] must be construed as granting to injured investors individual causes of action...."); see generally 9 Loss \& SELIGMAN, supra note 25, at 4335 (discussing reliance on $u b i$ jus).

27. See, e.g., Securities Investor Protection Corp. v. Barbour, 421 U.S. 412, 424 (1975) (holding that an implied cause of action is appropriate only when it "contains ... standards of conduct that a private action could help to enforce"); J.I. Case Co. v. Borak, 377 U.S. 426, 431-33 (1964) (holding that the "broad remedial purposes" of $\S 14$ (a) of the Securities Exchange Act of 1934 justified implication of a private action for improper proxy solicitation); Texas \& Pac. Ry. v. Rigsby, 241 U.S. 33, 39 (1916) (holding that it was the purpose of the Safety Appliance Acts to prevent violations of their provisions, whether by governmental enforcement or by implied action); cf. Merrill Lynch, 456 U.S. at 374 ("If a statute was enacted for the benefit of a special class, the judiciary normally recognized a remedy for members of that class."); Piper v. Chris-Craft Indus., 430 U.S. 1, 41-42 (1977) (refusing to imply a cause of action when the purpose of the statute was to protect a class other than the one to which the plaintiff belonged); Bell v. Hood, 327 U.S. 678, 684 (1946) (implying an action directly under the Fourth and Fifth Amendments; "[W] been invaded, it has been the rule from the beginning that courts will be alert to adjust their remedies so as to grant the necessary relief."). 
A gradual redefinition of this standard began in the early 1970 s amid growing dissatisfaction felt by certain members of the Court with existing standards for implied actions. ${ }^{28}$ The Court's discontent came to an apparent head in 1975 in Cort v. Ash. ${ }^{29}$ There a unanimous Court set forth a four-step inquiry to guide the analysis of implied cause of action questions. ${ }^{30}$ Under Cort, courts asked to recognize an implied action should consider: (1) whether the plaintiff is a member of the class for whose especial benefit the statute was enacted; (2) whether there is an indication of legislative intent to create or deny an implied remedy; (3) whether a private cause of action is consistent with the underlying purposes of the legislative scheme; and (4) whether the cause of action is one traditionally relegated to state law. ${ }^{31}$ While these factors purportedly did no more than distill the Court's existing jurisprudence, Cort is understood as a conservative milestone, marking the Court's clear break with the more permissive past. 32

Cort was nominally the leading implication decision for several years thereafter, but since it was decided, consensus on the implied right of action issue has broken down. In the ensuing years, the Supreme Court has made clear that federal courts should no longer feel free to provide remedies necessary to give effect to federal statutes. The courts instead must fulfill the clearly expressed intent of Congress, and only in exceptional cases may they look behind the language of a statute in order to determine that intent. ${ }^{33}$ Some have taken these later decisions virtually to end the doctrine of im-

28. See infra notes 33-35 and accompanying text.

29. 422 U.S. 66 (1975).

30. See 422 U.S. at 78.

31. See 422 U.S. at 78.

32. See Merrill Lynch, 456 U.S. at 377 (explaining that Cort found that "[t]he increased complexity of federal legislation and the increased volume of federal litigation strongly supported the desirability of a more careful scrutiny of legislative intent"); Cannon v. University of Chicago, 441 U.S. 677, 698 (1979) (noting that Cort and cases thereafter instituted a "strict approach"); Ashford, supra note 20, at 242-43 ("[A] number of jurists have viewed the . . four factors in Cort as a restrictive modification" of Borak, 377 U.S. 426, a securities law case that recognized virtually unlimited federal court power to create new remedies); John A. Maher, Implied Private Rights of Action and the Federal Securities Laws: A Historical Perspective, 37 WASH. \& LEE L. REv. 783, 796 (1980) (characterizing Cort as "reflect[ing] a great effort to restrain overenthusiasm in inferring causes of action").

33. Two cases decided in 1979 reaffirmed the Court's commitment to literal interpretation of statutes, as evidenced by its reluctance to imply causes of action, and made clear at the very least that the Cort standard was to become even more restrictive. See Transamerica Mortgage Advisors, Inc. v. Lewis, 444 U.S. 11, 15-16 (1979); Touche Ross \& Co. v. Redington, 442 U.S. 560, 575 (1979) ("II]n Cort v. Ash, the Court set forth four factors that it considered 'relevant' in [implying] a private remedy .... [But the] central inquiry remains whether Congress intended to create ... a private cause of action."). Thus, when legislative intent is clear, "there is no need for [courts] to "trudge through all four of the factors when the dispositive question of legislative intent has been resolved." Merrill Lynch, 456 U.S. at 388 (quoting Califomia v. Sierra Club, 451 U.S. 287, 302 (1981) (Rehnquist, J., concurring)). 
plication, ${ }^{34}$ and while it appears that "rumors about the death of the implied cause of action ... are exaggerated," 35 it is clear that plaintiffs now must overcome a high hurdle to convince federal courts to recognize implied private actions.

However, whatever the Court's current attitude toward implied actions section 10's most important attribute for present purposes is its age - RESPA was enacted more than twenty years ago. Prior to the narrowing Supreme Court decisions of the 1970s, Congress likely expected and relied on the federal courts to imply remedies. Congress may well have expected the courts to recognize a private cause of action for violations of section 10 automatically.

While the Court's recent implied action jurisprudence has not been entirely clear, it has recognized the significance of congressional reliance on statutory interpretation precedents, and accordingly it has adjusted its interpretive attitude when considering statutes enacted prior to Cort. In Cannon v. University of Chicago, ${ }^{36}$ the Court recognized an implied action under Title IX of the Education Amendments of 1972.37 While the Court made clear that generally it will "adhere to the strict approach followed in ... recent cases," "38 it explained that such an approach is not appropriate for pre-1975 statutes. ${ }^{39}$ The Court repeatedly emphasized that Title IX was enacted prior to Cort, and thus that it was necessary to "take into account [the] contemporary legal context" of the statutes being construed. ${ }^{40}$ This is so because "[i]t is always appropriate to assume that our elected representatives ... know the law,"41 and therefore "it is not only appropriate but also realistic to presume that Congress was thoroughly familiar with [pre-Cort precedents] and that it expected [a statute's] enactment to be interpreted in conformity with them." 42 Thus the law relevant to implication under RESPA is that which existed at the time of its enactment in 1974.43

34. See, e.g., Ashford, supra note 20, at 231 ("The continued vitality of these decisions [concerning the doctrine of implication] is questionable in light of recent significant changes in the Supreme Court's approach to implied liability ....").

35. Leist v. Simplot, 638 F.2d 283, 316 (2d Cir. 1980).

36. 441 U.S. 677 (1979).

37. 20 U.S.C. $\$ \$ 1681-87$ (1994).

38. Cannon, 441 U.S. at 698.

39. See 441 U.S. at 698.

40. 441 U.S. at $698-99$.

41. 441 U.S. at $696-97$.

42. 441 U.S. at 699.

43. It is worth noting that the "context" rule has gained increasing acceptance in modern decisions and is now used fairly routinely in contexts beyond that of implied actions. For example, in Molzof v. United States, 502 U.S. 301 (1992), the question at issue was what was meant by the term "punitive damages" in the Federal Tort Claims Act, 28 U.S.C. $\$ \$ 2671$ 2680 (1994). Section 2674 of that Act expressly prohibits awards of punitive damages against 
In more recent cases, the Court has reemphasized this "contemporary context" rule. In Merrill Lynch, Pierce, Fenner \& Smith, Inc. v. Curran, ${ }^{44}$ while the Court expressed fidelity to its new, conservative focus on facial evidence of legislative intent, it cautioned that the question of implication should begin with an examination of Congress's perception of the "contemporary legal context" in which the statute in question was enacted. ${ }^{45}$ Similarly, in Central Bank of Denver v. First Interstate Bank of Denver, ${ }^{46}$ while the Court explained that the explicit language of section 10(b) of the Securities Act of 1934 was sufficiently clear to resolve the issue whether to expand the existing private cause of action, 47 the Court added that if the statutory language had not been sufficiently clear, it would have been appropriate to attempt " to infer how the 1934 Congress would have addressed the issue[ ] had the [implied action] been included as an express provision in the 1934 Act." "48 Thus, while the language of a statute is dispositive in the interpretation of modern statutes, courts must interpret pre-Cort legislation with the "contemporary legal context" of the statute in mind..$^{49}$

As mentioned, the jurisprudence of the "contemporary context" rule has not been as clear as one might prefer. In particular, the

the United States. See 28 U.S.C. $\$ 2674$ (1994). To determine whether the damages sought by the Molzof plaintiff were "punitive," the Court considered the definition of that term in legal dictionaries in existence at the time the statute was enacted. The Court noted that when Congress uses legal terms of art in statutes, it is presumed to "'know[] and adopt[] the cluster of ideas that were attached to each borrowed word in the body of learning from which it was taken ...." Molzof, 502 U.S. at 307 (quoting Morissette v. United States, 342 U.S. 246, 263 (1952)). Similarly, in Blatchford v. Native Village of Noatak, 501 U.S. 775 (1991), an Alaskan native tribe sued the state of Alaska under a federal jurisdictional statute. The tribe claimed that Eleventh Amendment sovereign immunity was no bar to its claim because the statute implicitly abrogated such immunity. Notwithstanding that only two years earlier the Court had ruled that "[the] power to abrogate [sovereign immunity] can only be exercised by a clear legislative statement," 501 U.S. at 786 (citing Dellmuth v. Muth, 491 U.S. 223 (1989)), the Court dutifully considered the state of the law of sovereign immunity at the time the statute was enacted. See 501 U.S. at 787-88. See generally Nancy Eisenhauer, Note, Implied Causes of Action Under Federal Statutes: The Air Carriers Access Act of 1986, 59 U. CHn. L. REV. 1183, 1192-93 (1992).

44. 456 U.S. 353 (1982).

45. See 456 U.S. at $377-82$.

46. 511 U.S. 164 (1994).

47. The Court refused to extend further the cause of action that had already been implied under that statute. Its decision was based on its view that the statute, on its face, made clear that no such extension was intended. See 511 U.S. at 173-78.

48. 511 U.S. at 173 (quoting Musick, Peeler \& Garrett v. Employers Ins., 508 U.S. 286, 294 (1993)).

49. This is not to say that a statute's age necessarily resolves the issue - Touche Ross \& Co. v. Redington, 442 U.S. 560 (1979), and Transamerica Mortgage Advisors, Inc. v. Lewis, 444 U.S. 11 1979), both involved statutes enacted prior to Cort, but the Court refused to recognize implied actions in either decision. While the Court now prefers to make decisions purely by way of construction of the statutory language itself, however, federal courts still must look beyond the text of federal statutes to make inferences regarding that text when the plain language of the statute is unclear. 
few Supreme Court decisions addressing this issue do not explain whether the standard to be applied to pre-Cort legislation is simply the law of implication as it existed when the given statute was enacted, or whether it is some more restrictive standard - for example, that the analysis proceeds in the same manner as in cases involving modern statutes, but that "clear on its face" is given a much more liberal meaning. 50 The problem is complicated by the fact that in Cannon and Merrill Lynch, the two cases in which the Supreme Court actually applied the "contemporary context" rule in its holding, the Court actually considered amendments to statutes under which implied private actions had been recognized previously. ${ }^{51}$ Thus, while the "relevant inquiry is ... what [Congress's] perception of the state of the law was," "52 it is difficult to say exactly what level of proof will be required in order to show that Congress intended a statute to be enforced by private action.

\section{AN IMPLIEd Action Under Section 10}

This Part examines the factors modern courts might consider in deciding whether to imply an action under section 10 . The first and most important of these factors, discussed in section II.A, is the statute's language. Currently, courts stress the importance of statutory language over other factors as an index of legislative intent, and some have done so with respect to section 10.53 Section II.A, however, argues that evidence contained in the language of section 10 has been exaggerated by those courts that have refused to recognize a private action, and that the language itself cannot resolve the issue. Section II.B considers other factors that might be thought important. First, it considers the contemporary context in which RESPA was enacted. Second, it uses the Cort analysis as a convenient expedient to capture any residual concerns.

\section{A. The Language of Section 10}

Courts sometimes argue, even with respect to pre-Cort legislation, that the language of a given statute proves with sufficient clarity that no action was intended by Congress, and thus that the inquiry ends with a mere reading of the statutory language. 54 However, even under such a standard the explicit language of section 10

50. See, e.g., Central Bank of Denver, 511 U.S. at 173; Merrill Lynch, 456 U.S at 375-79.

51. See Merrill Lynch, 456 U.S. at 378; Cannon v. University of Chicago, 441 U.S. 677, 696-98 (1979). In such a case, the fact that Congress "acquiesces" in the existing enforcement rules by not overruling them is significant evidence that Congress intends for those enforcement rules to remain available. See Merrill Lynch, 456 U.S. at 381-82.

52. Merrill Lynch, 456 U.S. at 378 n.61 (quoting Brown v. GSA, 425 U.S. 820,828 (1976)).

53. See infra text accompanying notes 54-71.

54. See infra text accompanying notes 58-64. 
does not resolve the issue, and should not prevent courts from looking behind it to other indicia of legislative intent. In Central Bank of Denver, the Court held that the statute at issue was sufficiently clear because it simply did not contemplate the conduct complained of by the plaintiffs. ${ }^{55}$ Section 10 , by contrast, explicitly prohibits the conduct at issue in private section 10 actions. In Virginia Bankshares, Inc. $v$. Sandburg, 56 the Court went beyond the statute's language because the text and the legislative history surrounding it were silent with respect to remedy. .57 Similarly, section 10 is silent, and its language thus is not dispositive.

Courts that refuse to recognize a section 10 cause of action sometimes rely on the maxim expressio unius est exclusio alterius that to include one thing is to exclude all others - although they may not invoke it explicitly. That is, they argue that because some RESPA provisions provide private remedies and section 10 does not, Congress must not have intended there to be a section 10 private action. 58 For example, a lender who violates RESPA's notice and disclosure requirements ${ }^{59}$ is liable to the individual borrower in a private damages action. ${ }^{60}$ However, in each case in which RESPA explicitly provides a remedy it provides some unique sort of remedy. That is, it explicitly identifies a private remedy in order to make clear that some unusual sort of relief is appropriate for the given violation. For instance, plaintiffs who sue under the abovementioned notice and disclosure requirements are entitled to attorney's fees in addition to damages. ${ }^{61}$ Plaintiffs who allege violations of either RESPA's kickback or title insurance provisions may sue for treble damages. 62

Some courts make a similar argument with regard to the 1990 amendments to section 10 itself. Those amendments added a requirement that mortgagors receive periodic notices regarding the

55. See Central Bank of Denver, 511 U.S. at 177. The issue there was whether the already existing implied right of action under section 10(b) of the Securities Exchange Act of 1934 could support a suit against "aiders and abettors" of actions prohibited by that statute. The Court held that "it is inconsistent with settled methodology ... to extend liability beyond the scope of conduct prohibited by the statutory text." 511 U.S. at 177.

56. 501 U.S. 1083 (1991).

57. See 501 U.S. at 1103-05 (considering policy issues as determinative of an implied action question in a case in which "the Act's text and legislative history[,] mindful of [Congress's concern for the protection of the plaintiff class,] reveals little that would help toward understanding the intended scope of any private right").

58. See Allison v. Liberty Sav., 695 F.2d 1086, $1088-89$ (7th Cir. 1982) (" ‘Obviously . . when Congress wished to provide a private damage remedy, it knew how to do so and did so expressly." (quoting Touche Ross \& Co. v. Redington, 442 U.S. 560, 572 (1979))).

59. See 12 U.S.C. $\$ 2605$ (1994).

60. See 12 U.S.C. $\$ 2605(\mathfrak{f})$ (1994).

61. See 12 U.S.C. $\$ 2605(f)(3)(1994)$.

62. See 12 U.S.C. $\$ \S 2607$ (d), 2608(b) (1994). 
status of their escrow accounts. ${ }^{63}$ Failure to issue such notices is a violation of RESPA for which the Department of Housing and Urban Development ("HUD") is authorized to assess a penalty of fifty dollars per violation. The argument is that by specifically providing a remedy under section 10 , but by failing to provide a remedy tailored exclusively for violation of the escrow-payment limitations, Congress implied that no private remedy should be available for such a violation. ${ }^{64}$

This argument suffers from two significant weaknesses. First, the amendments say nothing concerning the more general prohibition on excess escrow payments, which still goes largely unenforced as a practical matter. The argument, then, apparently rests on the claim that Congress was more concerned with minor matters of mortgage administration than with section 10's basic, substantive prohibition. ${ }^{65}$ But it seems unlikely that Congress would express its intent against private enforcement of a statute, that otherwise remains useless, merely by addressing a minor, tangential point. Second, the amendments are silent with regard to private remedies. They add procedures by which HUD can punish violations of subsidiary provisions. It simply does not follow that, by providing these penalties, Congress expressed any intent with regard to private enforcement of the substantive provision. The remedies provisions currently existing in RESPA are simply irrelevant to the implication of a private action in section 10 .

Furthermore, the Supreme Court has, at least on occasion, intimated that arguments of this nature should no longer be made. Justice White set out an early exposition of their weaknesses when he wrote (in dissent):

The Court concludes that because the Act expressly provides for [administrative] enforcement proceedings, Congress must not have intended to create private rights of action. This application of the often criticized maxim expressio unius est exclusio alterius ignores our rejection of it in Cort v. Ash in the absence of specific support in the legislative history for the proposition that express statutory remedies are to be exclusive. 66

63. See 12 U.S.C. $\$ 2609$ (c) (1994).

64. See Louisiana v. Litton Mortgage Co., 50 F.3d 1298, 1301 (5th Cir. 1995) ("[W]hen Congress did amend Section $10 \ldots$ it added penalties for violations of a different provision of that section but not for violations of the provision limiting escrow deposit accounts.").

65. Section 10 is divided into several subparts. The excess-payment provision is the first subpart and is titled "In general." 12 U.S.C. \$ 2609(a) (1994).

66. Transamerica Mortgage Advisors, Inc. v. Lewis, 444 U.S. 11, 29 n.6 (1979) (White, J., dissenting) (citation omitted). 
Echoing this sentiment, Justice Marshall later wrote for a unanimous Court that "[we] reject application of the maxim of statutory construction, expressio unius est exclusio alterius."67

Admittedly, the Court has not consistently followed this rule. 68 But even to the extent that Justice Marshall's holding has not been adopted fully, its reasoning has considerable force. To be sure, courts sometimes argue that when a statute provides a remedy in one instance and not another, it should be inferred that Congress "knew how to provide a remedy when it wanted."69 But this legal fiction is problematic. After all, Congress knows how to provide a remedy all the time, and yet courts have implied remedies throughout this century. This suggests that sometimes, although Congress knows how to provide a remedy, it may have been unable to do so for reasons of political compromise, it may simply have forgotten to do so in a given instance, ${ }^{70}$ or it may have felt that the presence of a private remedy is sufficiently clear on the face of a statute and that it was unnecessary to spell one out explicitly. As Justice Traynor put it:

A statute may be dubious because those who sponsored it were not motivated to do so in the public interest or because those who enacted it did so without adequate knowledge or consideration of its objectives or implications. For all the vaunted responsiveness of legislatures to the will of the people, it is no secret that legislative committees, particularly those dominated by the elder statesmen of a seniority system, tend to dilute the reliability of statutes as expression of public policy. ${ }^{71}$

\section{B. Other Considerations}

If the language of section 10 leaves the question of private enforcement open, then courts must consider other indicia of legislative intent. Probably the most important of these is RESPA's age.

67. Herman \& MacLean v. Huddleston, 459 U.S. 375,387 n.23 (1983). See generally 9 Loss \& SELIGMAN, supra note 25 , at 4334-36.

68. This is evidenced by the fact that, on occasion, the Court still cites Transamerica and other decisions based on expressio unius with approval. See 9 Loss \& SELIGMan, supra note 25 , at $4334-36$.

69. Allison v. Liberty Sav., 695 F.2d 1086, 1088 (7th Cir. 1982).

70. For example, Judge Posner argued with respect to section 10's curious silence that Congress simply may have forgotten to provide a remedy. See Allison, 695 F.2d at 1092-93 (Posner, J., dissenting from denial of rehearing en banc). For him the question was whether, "if the Congress that enacted RESPA had adverted to the question of remedies for violations of section 10 , [it would] have decided that there ought to be a private damage remedy ...." 695 F.2d at 1092.

71. Hon. Roger J. Traynor, Statutes Revolving in Common-Law Orbits, 17 CATH. U. L. REv. 401, 424-25 (1968); see also Marc I. Steinberg, The Ramifications of Recent U.S. Supreme Court Decisions on Federal and State Securities Regulation, 70 Notre Dame L. REv. 489, 496 (1995) (arguing that Congress is often simply unable to give the courts the explicit guidance they might desire). 
Thus, this section first considers RESPA's "contemporary legal context" - the law of implication as it existed in 1974. Then, in order to reach whatever other factors courts might consider, this section concludes by subjecting section 10 to the Cort analysis.

\section{The Law in 1974}

The law of implication as it existed in 1974 would easily support an implied action under section 10. Rigsby was still the leading case at that time, so the basic inquiry was whether the plaintiff was "one of the class for whose especial benefit the statute was enacted ...."72 The statute in Rigsby was a bare regulatory provision that made no mention whatever of liability in private civil proceedings. ${ }^{73}$ However, the mere fact that it was intended to protect that class of which the plaintiff was a member was sufficient to support a private cause of action. RESPA has only one purpose: protection of individual consumers. It is beyond doubt that individual home buyers are the class for whose especial benefit Congress enacted section 10. The legislative history is replete with references to this effect. ${ }^{74}$ To be sure, the question of implied private causes of action was not free from doubt even in 1974. As mentioned above, ${ }^{75}$ the Court's decisions of the early 1970s showed signs of growing discontent with implied rights of action. ${ }^{76}$ Nevertheless, the Court by 1974 had not yet wholly discarded the permissiveness of Rigsby.

72. Texas \& Pac. Ry. v. Rigsby, 241 U.S. 33,39 (1916).

73. See Rigsby, 241 U.S. at 38-39. The statute at issue was the Federal Safety Appliance Act, ch. 196, $\S 2,27$ Stat. 531, 531 (1893) (repealed 1994), which required railroads to install safety devices on its railroad cars. The Act was to be enforced by "a penalty of one hundred dollars for each and every such violation, to be recovered in a suit or suits to be brought by the United States district attorney ...." Federal Safety Appliance Act, ch. 196, § 6, 27 Stat. 531, 532 (1893) (repealed 1994).

74. See 12 U.S.C. $\$ 2601$ (a) (1994) (explaining that RESPA's purpose is "to insure that consumers throughout the Nation . . . are protected from unnecessarily high settlement charges"); Charles G. Field, RESPA in a Nutshell, 11 Real Prop., ProB. \& Tr. L.J. 447, 44849 (1976) ("By passing RESPA, the Congress intended that the consumer be given sufficient information at an early enough time to permit shopping ... for the best settlement services and costs ... . Congress certainly intended that the abusive practices . . . be eliminated.").

75. See supra notes $28-35$ and accompanying text.

76. In a handful of cases predating RESPA's enactment, the Supreme Court initiated its first doubts about the propriety of the Rigsby standard, and thus by 1974, the Court had begun to cast some doubt on the power of courts to imply private actions. Professors Loss and Seligman call this period the "back to orthodoxy" stage, which immediately preceded the "shift of presumption" stage brought about by Cort and later decisions. See 9 Loss \& Selio. MAN, supra note 25, at 4324. In the Supreme Court's 1971 decision in Bivens v. Six Unknown Named Agents of the Fed. Bureau of Narcotics, 403 U.S. 388 (1971), the Court implied an action directly under the Fourth Amendment. Justice Harlan concurred, but was somewhat critical of the Court's apparent belief that the doctrine of implication is merely an innocuous act of statutory construction. He argued that " $[t]$ he notion of 'implying' a remedy . . . can only refer to a process whereby the federal judiciary exercises a choice among traditionally available judicial remedies" rather than to a mere search for statutory meaning. 403 U.S. at 403 n.4 (Harlan, J., concurring). Chief Justice Burger went considerably further in his rather heated dissent, arguing that courts simply are not qualified to decide questions of enforce- 
After all, Cort itself recognized an implied right of action in the case of "a bare criminal statute, with absolutely no indication that civil enforcement of any kind was available to anyone."77 Thus, if the question had arisen in 1974, section 10 should have passed muster quite easily and a private cause of action been recognized.

The implications of this analysis, as indicated earlier, ${ }^{78}$ are not entirely clear. What is clear is that "the contemporary legal context" in which RESPA was enacted was considerably more permissive than that which exists today, and that fact alone tips the scales in favor of a private action. ${ }^{79}$

\section{The Cort Factors}

The Cort factors provide a convenient means to analyze whatever residual concerns may remain after consideration of the contemporary context. The Cort factors are: (1) whether the plaintiff is a member of the class for whose especial benefit the statute was enacted, (2) whether there is an indication of legislative intent to create a private right of action, (3) whether the private cause of action is consistent with the underlying purposes of the legislative scheme, and (4) whether the cause of action is one traditionally relegated to state law. 80 All of the Cort factors support recognition of a section 10 cause of action.

Cort first asks whether the plaintiff is a member of the class protected by the statute. This, of course, is merely a restatement of the

ment. "Legislation," he argued, "is the business of the Congress." 403 U.S. at 412 (Burger, C.J., dissenting).

In cases immediately following Bivens, the Court expressed growing concern with its own capacity to infer remedies. In National R.R. Passenger Corp. v. National Assn. of R.R. Passengers (Amtrak), 414 U.S. 453 (1974), decided the same year that RESPA became law, the Court refused to imply an action on behalf of a national passengers' union against the Amtrak corporation. The Court engaged in a lengthy analysis of the Amtrak Act's history to conclude that legislative intent precluded a private action. Such an examination stood in notable contrast to the terse reasoning of Rigsby and its progeny. See also SIPC v. Barbour, 421 U.S. 412, 418 (1975) (refusing to imply an action merely because the statute did not preclude an action, in contrast to a sentiment that had been expressed in earlier cases, like Reitmeister v. Reitmeister, 162 F.2d 691, 694 (2d Cir. 1947), that "in the absence of contrary implications ... a criminal statute, enacted for the protection of a specified class, [creates] a civil right in members of the class").

77. Cort v. Ash, 422 U.S. 66,80 (1975). Similarly, notwithstanding the skeptical minority views in Bivens, the majority in that case applied a standard arguably as broad as that in Rigsby. See Bivens, 403 U.S. at 395-96 (recognizing an implied private action because "damages [are] regarded as the ordinary remedy for an invasion of personal interests in liberty .... ' $[\mathrm{I}] \mathrm{t}$ is ... well settled that where legal rights have been invaded, and a federal statute provides for a general right to sue for such invasion, federal courts may use any available remedy to make good the wrong done." (citation omitted)).

78. See supra notes 50-52 and accompanying text.

79. See supra notes 50-52 and accompanying text.

80. See Cort, 422 U.S. at 78. 
Rigsby standard, and was discussed above. ${ }^{81}$ Therefore, the protected-class element of the Cort inquiry is easily satisfied.

The second Cort factor asks whether there is an indication of legislative intent to create a private action. Like the language of the statute, section 10's legislative history contains no explicit endorsement or denial of a private cause of action. Most courts that have considered section 10 have held its history to be inconclusive. ${ }^{82}$ The Sixth Circuit - in an unusually unrestrained opinion for the post-Cort period - suggested in a footnote that the legislative history was sufficient evidence in itself of the implied action. ${ }^{83}$ The court did not claim, however, that Congress had explicitly mandated such an action.

RESPA's protective purpose, clearly established by its legislative history, supports recognition of an implied action, even if its history is silent as to enforcement. ${ }^{84}$ As Justice Stevens explained in his opinion for the Cannon majority, when "it is clear that federal law has granted a class of persons certain rights, it is not necessary to show an intention to create a private cause of action, although an explicit purpose to deny such an action would be controlling." 85 That must be the case, or actions would never be implied. ${ }^{86}$

Third, Cort requires courts to consider whether the proposed implied action is consistent with the purpose of the statute. A private action is consistent with RESPA's purpose because it would allow consumers themselves to vindicate their rights. An implied cause of action is the means best suited to serving the purposes of the statute, and, as will be discussed below, it is the means most consistent with the attitudes of RESPA's drafters. ${ }^{87}$

Finally, Cort requires that courts consider whether a given cause of action is properly a matter of state concern. ${ }^{88}$ Regulation of

81. See supra text accompanying notes 72-74.

82. See, e.g., Louisiana v. Litton Mortgage Co., 50 F.3d 1298, 1301 (5th Cir. 1995) ("[T] 1089 (7th Cir. 1982) ("The parties' briefs, the district court's opinion and our own research disclose no legislative history on the issue ....").

83. See Vega v. First Fed. Sav. \& Loan Assn., 622 F.2d 918, 925 n.8 (6th Cir. 1979) ("[W]e believe, based on the legislative history, that Congress intended to create a private remedy for violations of the Act.").

84. See, e.g., S. REP. No. 93-866, at 8 (1974) ("[T]his provision will result in substantial savings to the home buyer at the time of settlement ....").

85. Cannon v. University of Chicago, 441 U.S. 677, 694 (1979) (quoting Cort v. Ash, 422 U.S. 66, 82 (1975)).

86. See Transamerica Mortgage Advisors, Inc. v. Lewis, 444 U.S. 11, 18 (1979) (remarking that the silence of the legislative history is "not surprising when it is remembered that the Act concededly does not explicitly provide any private remedies whatever").

87. See infra notes 104-07 and accompanying text.

88. The Supreme Court decisions of the late 1970 s deemphasized this criterion and made clear that a showing that a given area of the law is properly federal is not enough, on its own, 
mortgage escrow accounts is not an area traditionally within state purview. Escrow accounts first appeared in the 1930s and went virtually unregulated until the enactment of the RESPA's immediate federal predecessors in the early 1970s. ${ }^{89}$ Only a few states have enacted laws in this area, ${ }^{90}$ and those that have take a notably different approach than section 10.91 These state statutes have no common law antecedents. Furthermore, RESPA applies only to "federally related" mortgages - that is, mortgages made by a lender that is insured or regulated by the federal government. ${ }^{92}$ Finally, RESPA explicitly preempts inconsistent state law. ${ }^{93}$ Therefore, to the extent that state escrow law exists, federal law controls. Escrow administration, then, is a matter of decidedly federal law. And thus, in sum, even the comparatively conservative Cort inquiry strongly supports recognition of an implied cause of action. ${ }^{94}$

\section{The Superiority of An Action for Money Damages}

This Part seeks to show that public policy favors private enforcement. Section III.A argues that if RESPA's escrow rule is to be given any teeth, the appropriate means to do so is a private action for money damages. Administrative enforcement or even private remedies other than a damages action will be inferior. Section III.B puts forth several final considerations that weigh in favor of a damages action.

to imply an action. See Transamerica, 444 U.S. at 23-24; Touche Ross v. Redington, 442 U.S. $560,575-76$ (1979). Those decisions also seem to indicate, however, that in order to imply an action, this factor, along with all the others, must be satisfied.

89. See Skehan, supra note 4, at 793 (discussing the history of the escrow-account practice).

90. See, e.g., Conn. Gen. Stat. Ann. § 49-2a (West 1994); Mass. Gen. Laws ch. 183, § 61 (1994); N.Y. Banking LaW \& 14-b (McKinney 1990).

91. The state statutes that exist place no cap on the amount of escrow requirements, but instead require that the borrower receive interest for the escrowed funds. See Skehan, supra note 4, at $790 \mathrm{n} .10$ (discussing statutes of Connecticut, Massachusetts, and New York).

92. See 12 U.S.C. \$ 2602(1) (1994); see also 4 Richard R. Powell \& Patrick J. Rohan, POWELL ON REAL PROPERTY I 37A.02[2] (1996) (discussing the scope of RESPA coverage).

93. See 12 U.S.C. \& 2616 (1994).

94. Some courts refuse to recognize implied actions for policy reasons. For instance, the Virginia Bankshares court refused to expand liability in the case of section 14(a) of the 1934 Securities Exchange Act in part because of the evidentiary difficulties involved - investor plaintiffs would have to prove purely speculative claims as to the value their securities might have had if the offending corporate transaction had not occurred. See Virginia Bankshares, Inc. v. Sandburg, 501 U.S. 1083, 1105-06 (1991) (relying on Blue Chip Stamps v. Manor Drug Stores, 421 U.S. 723, 742-43 (1975)). No such difficulties are implicated in the case of section 10. Plaintiffs would merely show that the amount required in the mortgage agreement exceeds that required by section 10 's statutory formula. 


\section{A. Failure of Alternative Remedies}

An implied cause of action for money damages would be unnecessary if other means of enforcing section 10 were effective. For example, plaintiffs might pursue private equitable or self-help remedies or administrative enforcement might be available. As this section shows, however, such alternative remedies cannot adequately address the needs of mortgage borrowers or achieve RESPA's goals.

The most viable alternative, administrative enforcement of section 10 , would be inadequate. HUD is the only government entity likely to hold section 10 enforcement authority. Although not specifically designated to enforce section 10,95 HUD is empowered to enforce some of RESPA's other provisions ${ }^{96}$ - although that general authority is nowhere set out in the statute. ${ }^{97}$ HUD apparently has no interest in enforcing section 10, however, and it might not even be empowered to do so. HUD originally took the view that its authority extended no further than to various of RESPA's disclosure provisions - that is, that it had no regulatory jurisdiction whatsoever with respect to section 10.98 The set of rules initially enacted by HUD under RESPA, known as "Regulation X," contained no rules concerning section 10.99 When HUD did finally address section 10, after nearly twenty years, its rules contained only interpretive guidance concerning accounting and administrative practices. ${ }^{100}$ The rules do little more than restate and clarify section 10 itself, adding only several statutory definitions ${ }^{101}$ and certain

95. HUD is given rulemaking and interpretive powers, but no general enforcement power. See 12 U.S.C. \$ 2617(a) (1994).

96. RESPA explicitly assigns the following functions to HUD: (1) issuing "uniform settlement statement[s]," a form to be used in all transactions involving loans subject to RESPA, see 12 U.S.C. $\$ 2603$ (1994); (2) preparing an explanatory booklet to apprise borrowers of their rights under RESPA, see 12 U.S.C. $\$ 2604$ (1994); (3) promulgating rules concerning kickbacks and other uneamed fees in the mortgage settlement process, see 12 U.S.C. $\S 2607$ (c) (1994), and prosecuting violations of the kickback rules, see 12 U.S.C. $\$ 2607$ (d)(4) (1994); and (4) administering model land recordation systems in various parts of the United States on a demonstration basis, see 12 U.S.C. $\$ 2611$ (1994).

97. Note the irony: some courts, purportedly wary of inferring legislative intent with regard to private enforcement, argue that administrative enforcement is adequate. Administrative enforcement authority, however, is nowhere set out in section 10. Such authority, therefore, must also be implied.

98. See Whitman, supra note 10, at 234 (describing HUD's early hesitancy to exercise its RESPA rulemaking power in any area except certain cost-disclosure provisions). X.").

99. See id. ("[O]nly [the disclosure] provisions of RESPA ... are amplified in Regulation

100. See 24 C.F.R. $\S 3500.17$ (1996) (interpreting section 10 , but setting forth no enforcement provisions).

101. See 24 C.F.R. $\$ 3500.17$ (b) (1996) (defining numerous statutory terms found in section 10 and Regulation $X$, none of which relates to enforcement). 
rules governing acceptable accounting procedures. ${ }^{102}$ They make no mention of enforcement of the escrow limitation. ${ }^{103}$

Furthermore, RESPA's drafters expressed animosity toward government expansion, which strongly suggests they intended section 10 to be enforced by means other than bureaucratic oversight. The Senate Committee on Banking, Housing and Urban Affairs, the committee of jurisdiction over RESPA, made clear its intent to protect housing consumers without expanding the federal bureaucracy. 104 RESPA's predecessor, section 701 of the Emergency Home Finance Act of 1970, ${ }^{105}$ required HUD and the Veterans' Administration to regulate directly the fees imposed in connection with real estate settlement.106 RESPA repealed these "rate regulation" provisions because they required burdensome federal micromanagement. RESPA further rejected any similar proposed regulations in favor of less bureaucratic oversight. ${ }^{107}$

In addition, administrative agencies are simply not equipped to enforce section 10 as well as private litigants are. Even if HUD were empowered to enforce section 10, RESPA is only one small part of HUD's wide range of responsibilities, and section 10 is only one provision of RESPA. ${ }^{108}$ The Supreme Court itself raised a very similar argument to support its recognition of an implied action in Cannon v. University of Chicago. ${ }^{109}$ There the Court pointed out that a private action was necessary to effectuate the purposes of Title IX of the Education Amendments of 1972 because the Department of Health, Education, and Welfare ("HEW"), by its own admission, was unable to enforce the statute effectively. ${ }^{110}$

102. See 24 C.F.R. $\$ \$ 3500.17(c)(2)-(4), 3500.17$ (d) (1996).

103. HUD's rule contains penalty provisions for a subsidiary provision of section 10 , concerning escrow account statements. See 24 C.F.R. $\$ 3500.17(m)-(n)$ (1996). These provisions, however, are virtually identical to the penalty provision contained in section 10 itself with respect to failure to issue escrow statements. See 15 U.S.C. \$ 2609(d) (1994). They say nothing with regard to violations of the more general escrow limitation itself.

104. See S. REP. No. 93-866, at 4-5 (1974); H.R. REP. No. 93-1177, at 5 (1974) (heavy administrative involvement is "likely to create a bureaucratic monstrosity" (citation omitted)) .

105. Pub. L. No. 91-351, § 701, 84 Stat. 450 (1970).

106. See S. REP. No. 93-866, at 4-5 (1974) (characterizing the prior legislation).

107. See id.

108. Illustrative of the breadth of HUD's duties is the fact that the body of HUD regulations fills seven full volumes of the Code of Federal Regulations, totaling 4,375 pages. See 24 C.F.R. $\$ \S 0.735-101$ to 4100.4 (1996). The sole provision relevant to section 10 takes up only 11 of those pages. See 24 C.F.R. \& 3500.17 (1996).

109. 441 U.S. 677 (1979).

110. See 441 U.S. at $708 \&$ n. 42 . In submissions to the Court in the Cannon proceedings, HEW admitted that it did not have the resources necessary to enforce Title IX adequately. HEW wrote that:

As a practical matter, HEW cannot hope to police all federaliy funded education programs, and even if administrative enforcement were always feasible, it often might not 
Finally, even if HUD were empowered to enforce section 10, the reach of its authority would be incomplete. At least some mortgage borrowers would fall through the cracks of administrative enforcement authority because some lenders covered by RESPA are not overseen by HUD or any other federal regulatory agency. For example, a bank may be subject to RESPA's escrow-payment limitation because it makes residential loans in excess of one million dollars per year, ${ }^{111}$ but not be overseen by any administrative body with RESPA enforcement authority because it is a private institution that receives no federal insurance protection. ${ }^{112}$ Therefore, HUD and other federal agencies, even if they had any intention of enforcing section 10, could not intercede in cases of RESPA violations by such an institution.

Furthermore, a damages action is superior to alternative private remedies. Plaintiffs could resort to some sort of self-help style remedy, such as simple refusal to make excess escrow payments. If the lender sought to recover such payments, section 10 could be raised as an affirmative defense. This self-help action would be taken at the borrower's peril, however, because the courts might also disapprove of extrajudicial action on the part of individual borrowers.

Injunctive forms of relief would also be inadequate. Equitable remedies might be useful if available prior to section 10 violations. However, if a borrower is able to identify excess escrow requirements in a financing agreement prior to entering the agreement he would simply take his business elsewhere rather than seek some sort of judicial relief. Similarly, postviolation equitable relief would

redress individual injuries. An implied private right of action is necessary to ensure that

the fundamental purpose of Title IX . . . is achieved.

441 U.S. at 708 n.42 (quoting Reply Brief for Federal Respondents 6).

111. RESPA applies only in cases involving a "federally related mortgage loan," as defined in 12 U.S.C. $\$ 2602(1)$ (1994). These loans fall into four categories:

(1) those made, in whole or in part, by lenders that are regulated or insured by any federal agency;

(2) those made, in whole or in part, by HUD or any other federal agency, in connection with any federal housing program;

(3) those made by any lender that intends to sell them, directly or indirectly, to the Federal National Mortgage Association or the Government National Mortgage Association; and

(4) those made by certain private lenders that loan or invest more than $\$ 1,000,000$ annu-

ally in residential real estate.

12 U.S.C. § 2602(1)(B) (1994). It is the final class of lenders that is of interest; institutions falling in this category might go wholly unregulated by any government entity that could conceivably enforce RESPA.

112. The only possible exception is the Federal Trade Commission ("FTC"). See 15 U.S.C. $\$ 1607$ (c) (1994) (granting the FTC general authority to enforce the Consumer Credit Cost Disclosure Act, 15 U.S.C. \$§ 1601-93 (1994), which governs a range of private lenders). It is not at all clear, however, that the FTC will ever enforce section 10. See Allison v. Liberty Sav., 695 F.2d 1086, 1090 n.8 (7th Cir. 1982) (suggesting that the FTC might have some section 10 authority over this class of lenders, but noting that it has never used such authority). 
be of little use because while a court might enjoin the abusive practice, an equitable order would not restore funds already wrongfully gotten.

\section{B. Why an Action for Money Damages?}

A private damages action presents several advantages over these alternative remedies, particularly over administrative response. First of all, only a damages remedy will allow plaintiffs to recover prejudgment interest on the escrowed funds. ${ }^{113}$ The underlying escrow funds themselves are of no real use to the lender they must be applied toward tax or other obligations, or be returned to the borrower. The lender's real interest in retaining excess escrow funds is that it is able to retain the interest on the excess funds. Thus, merely requiring lenders to return excess funds upon discovery of a section 10 violation allows them to profit from the violation and works no penalty. As Judge Posner put it, "[y]ou may not steal a man's pregnant cow and after it has given birth return the cow and keep the calf."114 Thus, a private damages action will prevent windfalls to lenders and make borrower plaintiffs whole.

Other advantages include the superior ability of private plaintiffs to monitor their own affairs. A federal enforcer must oversee many thousands of lenders, whereas the private plaintiff must monitor only one. Individual consumers, by contrast, have no interest to serve but their own, and thus are likely to pursue enforcement more diligently. Furthermore, private suits spread the costs of litigation. To be sure, not all mortgage borrowers are well suited to bear the costs of suit, and some might benefit from an allocation of federal resources to the extent they exist. But whatever hardship may be associated with the costs of litigation, private and administrative remedies are not mutually exclusive: if HUD or some other entity

113. Such awards may be made in conjunction with implied damages remedies even when the remedy is implied from a statute that does not provide for such interest. See Blau v. Lehman, 368 U.S. 403, 414 (1962) (citing Board of Commrs. v. United States, 308 U.S. 343, 352 (1939) (with regard to an action implied under section 16(b) of the Securities Exchange Act of 1934: "interest is not recovered according to a rigid theory of compensation for money withheld, but is given in response to considerations of faimess' ")); see also Rodgers v. United States, 332 U.S. 371, 373 (1947) ("[T] he failure to mention interest in statutes which create obligations has not been interpreted by this Court as manifesting an unequivocal congressional purpose that the obligation shall not bear interest.").

Interest will generally be awarded unless for some reason it would be unfair. See Anixter v. Home-Stake Prod. Co., 977 F.2d 1549, 1554 (10th Cir. 1992) ("Despite the general availability of prejudgment interest absent some justification for withholding it, federal law does not make it available as a matter of right."). In particular, awards of interest may not be punitive in nature - that is, they must be compensatory. See Anixter, 977 F.2d at 1554; Wolf v. Frank, 477 F.2d 467, 479 (5th Cir. 1973). Further, prejudgment interest is distinct from consequential damages based on the lost use of money. Interest merely compensates the plaintiff for the lost time-value of his money. See Madigan, Inc. v. Goodman, 498 F.2d 233, 238-40 (7th Cir. 1974) (distinguishing between profits of lost investments and interest).

114. Allison, 695 F.2d at 1092 (Posner, J., dissenting). 
does indeed have enforcement authority, the implication of a private action would not diminish that authority. Federal resources, if they currently exist to any extent, would still be available to vindicate the rights of borrowers unable to bear private litigation burdens. ${ }^{115}$ Furthermore, the hardships of litigation are outweighed by the loss that the entire class of mortgage consumers generally would suffer if section 10 were to go completely unenforced - the likely consequence of refusing to imply a private cause of action. ${ }^{116}$

But will plaintiffs take advantage of private damage actions if they are available? Escrow overcharges sometimes may not be large enough in themselves to motivate litigation. ${ }^{117}$ Nonetheless, because escrow violations are often discovered along with other abuses in the lending process, section 10 claims most commonly arise in connection with claims of other violations, either under RESPA itself or under other consumer protection regulations such as the Truth in Lending Act.118 Moreover, section 10 damages and the attendant prejudgment interest are not always inconsequential. Mortgage loans on residential housing tend to be long-term transactions; therefore, if a borrower recognizes the overcharge at the end of a period of many years, the accrued interest could be substantial. Finally, because section 10 actions are often brought as class actions, ${ }^{119}$ the potential for class action damages could significantly defray litigation costs.

Finally, one might argue that the addition of section 10 damages actions to the overcrowded dockets of the federal courts would drain already limited judicial resources. ${ }^{120}$ However, plaintiffs generally bring section 10 claims along with other causes of action for which there are explicit rights to sue. ${ }^{121}$ Therefore, the recognition

115. In any event, no allocation of federal resources seems forthcoming, whether to protect mortgagors of limited means or otherwise.

116. In fact, in the absence of private enforcement, section 10 remains largely unused. See AtTORNeys General Report, supra note 12, at app. III-2.

117. See supra notes 13-15 and accompanying text.

118. See supra note 16.

119. See, e.g., Louisiana v. Litton Mortgage Co., 50 F.3d 1298 (5th Cir. 1995); Herrmann v. Meridian Mortgage Corp., 901 F. Supp. 915 (E.D. Pa. 1995); Lake v. First Nationwide Bank, 900 F. Supp. 726 (E.D. Pa. 1995); Michels v. Resolution Trust Corp.. No. 4-93-1167, 1994 WL 242162 (D. Minn. Apr. 13, 1994).

120. See Merrill Lynch, Pierce, Fenner \& Smith, Inc. v. Curran, 456 U.S. 353, 409 n.17 (1982) (Powell, J., dissenting); Allison v. Liberty Sav., 695 F.2d 1086, 1091 (7th Cir. 1982) (Posner, J., dissenting from denial of rehearing en banc) (noting that implication of an action will impose costs on the federal courts).

121. For example, escrow abuses are often challenged under the residential mortgage disclosure provision of the Truth in Lending Act, see 15 U.S.C. $\$ 1639$ (1994). Violation of that provision gives rise to an action for rescission of the transaction, see 15 U.S.C. $\$ 1635$ (1994), and potentially for other relief. See 15 U.S.C. \$ 1635(g) (1994) (other relief available as necessary); see also supra note 16. 
of an action in the case of section 10 will likely result in no new litigation, and little appreciable cost for the judiciary.

\section{CoNCLUSION}

Consumers should enjoy a private cause of action under section 10 of RESPA. Lenders can effectively ignore borrowers' rights under section 10 if those rights are left solely to administrative enforcement. The current refusals of many federal courts to recognize a section 10 action is thus rather ironic: by stridently refusing to act without evidence of legislative intent, they seriously frustrate legislative intent. This is an unnecessary outcome (of a sort that the Supreme Court once considered "a monstrous absurdity in a well organized government"122), because the statute and the circumstances surrounding it favor the implication of a private remedy under current law. A Congress whose express purpose was to "protect [consumers] from . . . abusive practices,"123 and that had for decades known the federal judiciary to be active in the fashioning of judicial remedies, would intend for the courts to allow private litigants to sue.

122. Kendall v. United States, 37 U.S. (12 Pet.) 524, 624 (1838).

123. 12 U.S.C. \& 2601(a) (1994). 


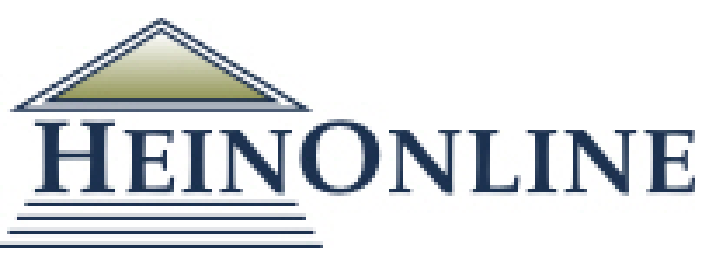

Content downloaded/printed from

HeinOnline

Mon Nov 4 18:36:44 2019

Citations:

Bluebook 20th ed.

Christopher L. Sagers, Implied Cause of Action under the Real Estate Settlement

Procedures Act, 95 Mich. L. Rev. 1381 (1997).

ALWD 6th ed.

Christopher L. Sagers, Implied Cause of Action under the Real Estate Settlement

Procedures Act, 95 Mich. L. Rev. 1381 (1997).

APA 6th ed.

Sagers, C. L. (1997). Implied cause of action under the real estate settlement procedures act. Michigan Law Review, 95(5), 1381-1403.

Chicago 7th ed.

Christopher L. Sagers, "Implied Cause of Action under the Real Estate Settlement

Procedures Act," Michigan Law Review 95, no. 5 (March 1997): 1381-1403

McGill Guide 9th ed.

Christopher L Sagers, "Implied Cause of Action under the Real Estate Settlement

Procedures Act" (1997) 95:5 Mich L Rev 1381.

MLA 8th ed.

Sagers, Christopher L. "Implied Cause of Action under the Real Estate Settlement Procedures Act." Michigan Law Review, vol. 95, no. 5, March 1997, p. 1381-1403.

HeinOnline.

OSCOLA 4th ed.

Christopher L Sagers, 'Implied Cause of Action under the Real Estate Settlement

Procedures Act' (1997) 95 Mich L Rev 1381

Provided by:

Cleveland-Marshall College of Law Library

-- Your use of this HeinOnline PDF indicates your acceptance of HeinOnline's Terms and Conditions of the license agreement available at https://heinonline.org/HOL/License

-- The search text of this PDF is generated from uncorrected OCR text.

-- To obtain permission to use this article beyond the scope of your license, please use: Copyright Information

Use QR Code reader to send PDF to your smartphone or tablet device

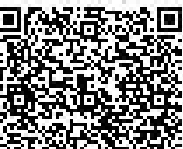

